\title{
Pollen- and Dispersal Units
}

monad - 132

dyad -134

pseudomonad - 135

tetrad - 137

tetrad tetrahedral - 138

tetrad decussate - 142

tetrad planar - 143

polyad - 145

massula - 147

pollinium - 148

pollinarium - 150 


\section{monad}

unit consisting of a single pollen grain
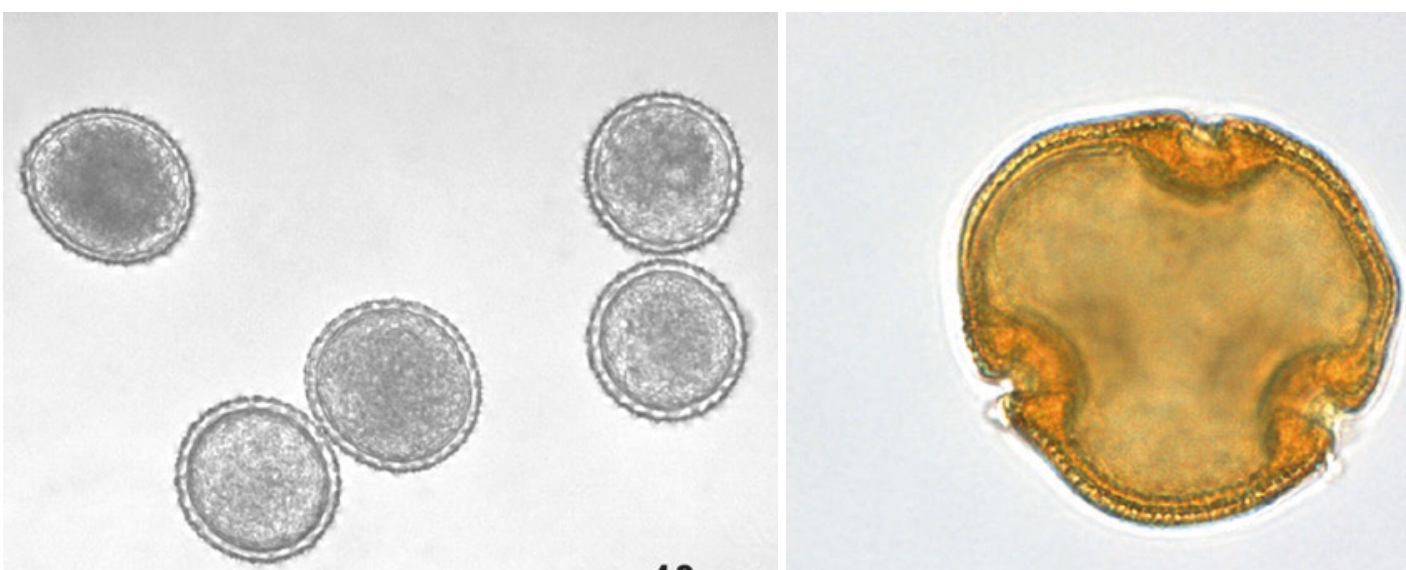

$10 \mu \mathrm{m}$
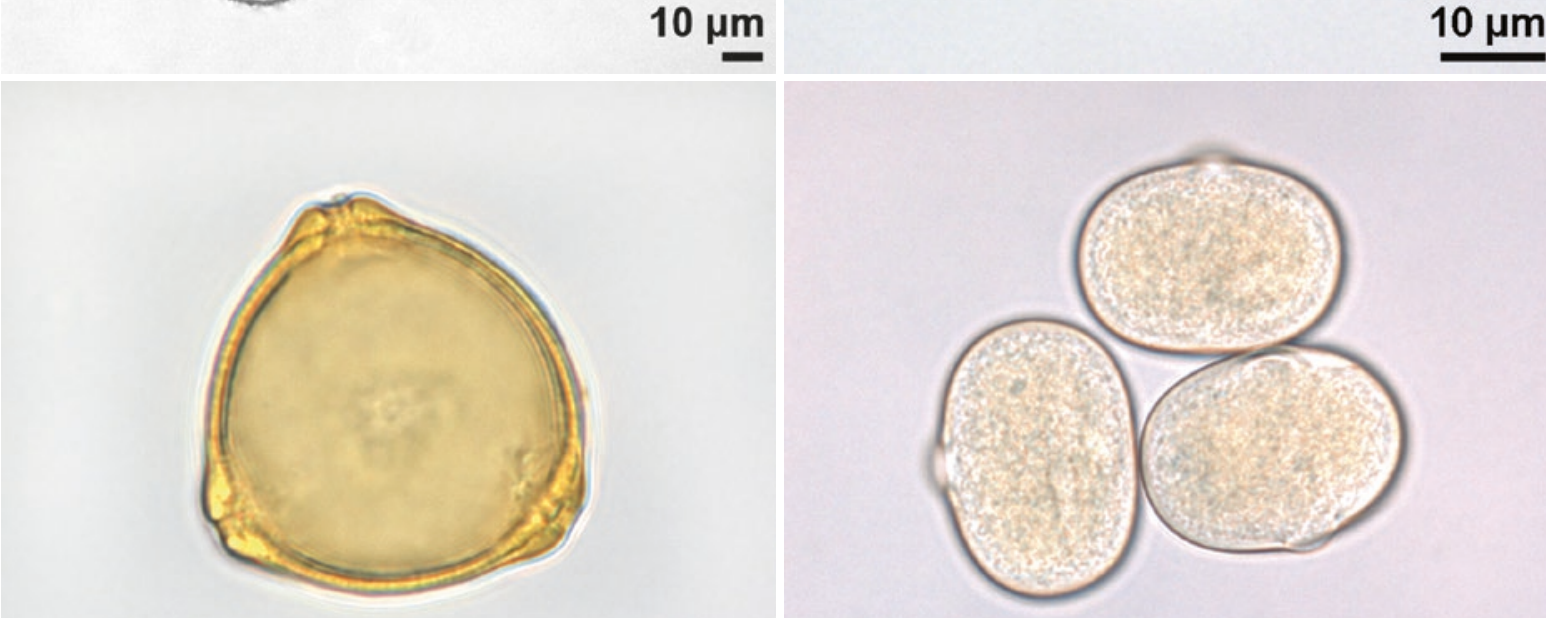

$10 \mu \mathrm{m}$

$10 \mu \mathrm{m}$

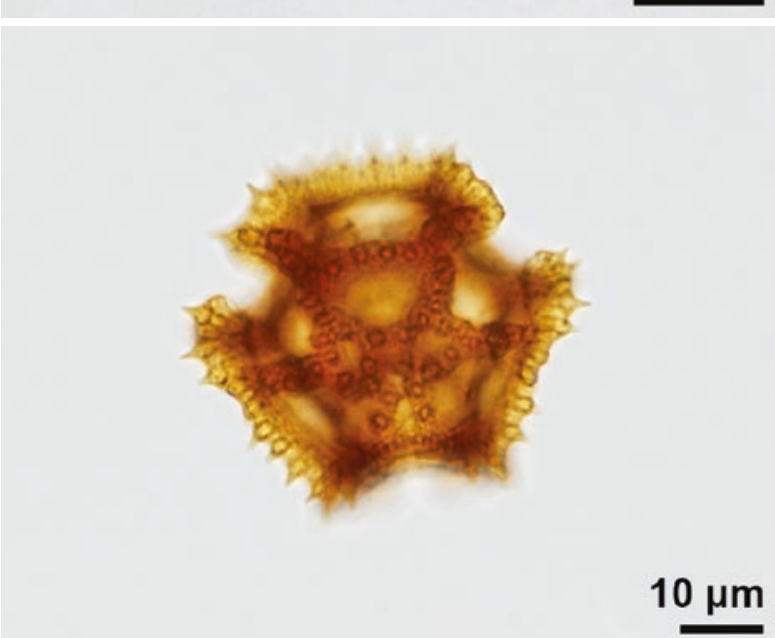

- Alocasia odora, Araceae

-

inaperturate pollen, hydrated

Tilia tomentosa, Malvaceae

tricolporate, polar view

Betula humilis, Betulaceae

triporate, polar view

Lathyrus pratensis, Fabaceae

tricolporate, equatorial view, hydrated

Tragopogon orientalis, Asteraceae

- tricolporate, oblique polar view

Gonatopus bovinii, Araceae

ring-like aperture, equatorial view, hydrated 

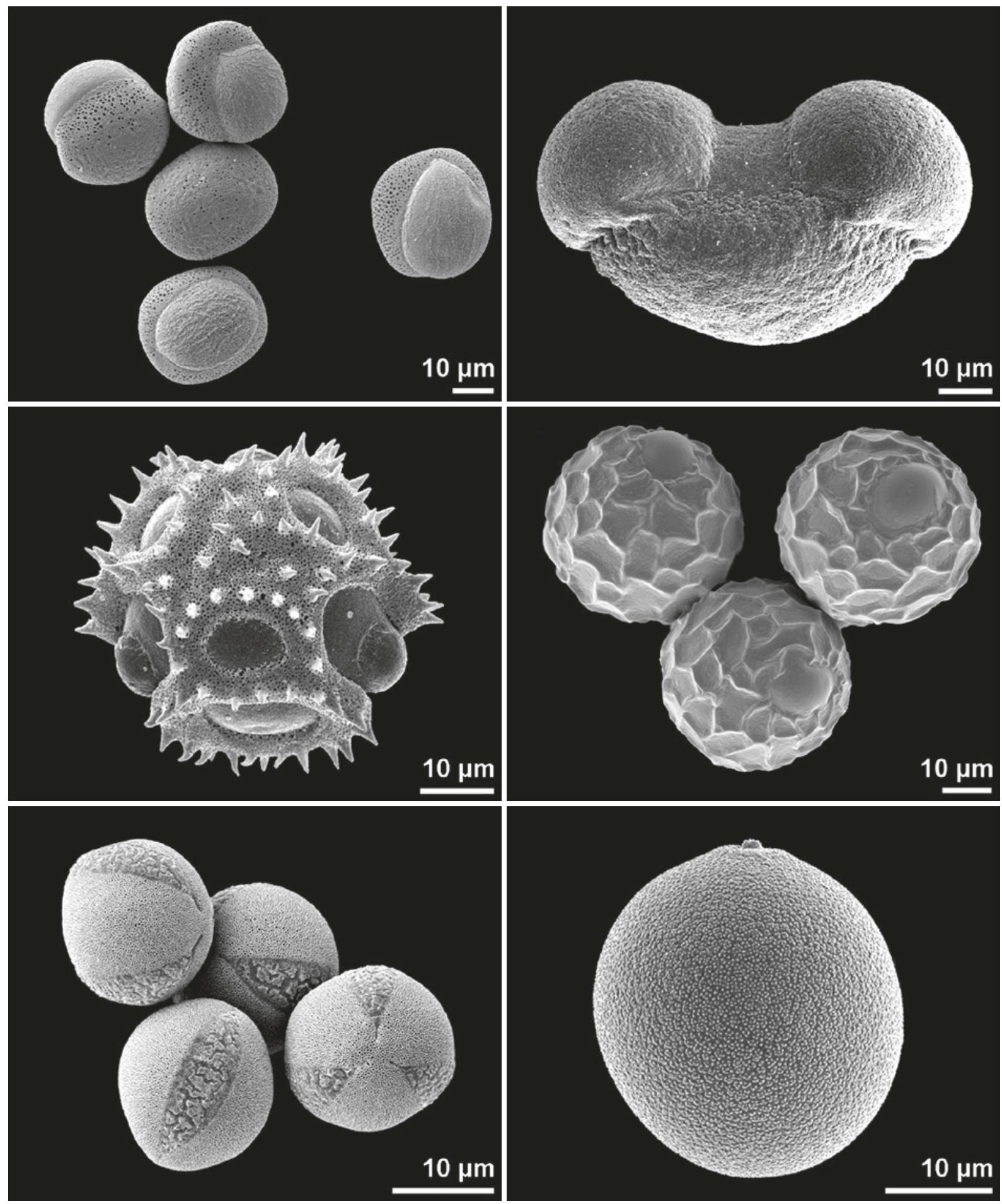

- Haworthia herbacea, Xanthorrhoeaceae

- Pinus strobus, Pinaceae sulcate

bisaccate, equatorial view

- Tragopogon orientalis, Asteraceae

- Bituminaria bituminosa, Fabaceae

tricolporate, oblique polar view

tricolporate, dry pollen

Dactylis glomerata, Poaceae

Lamium galeobdolon, Lamiaceae

- tricolpate

- ulcerate, equatorial view 
dyad

unit of two pollen grains
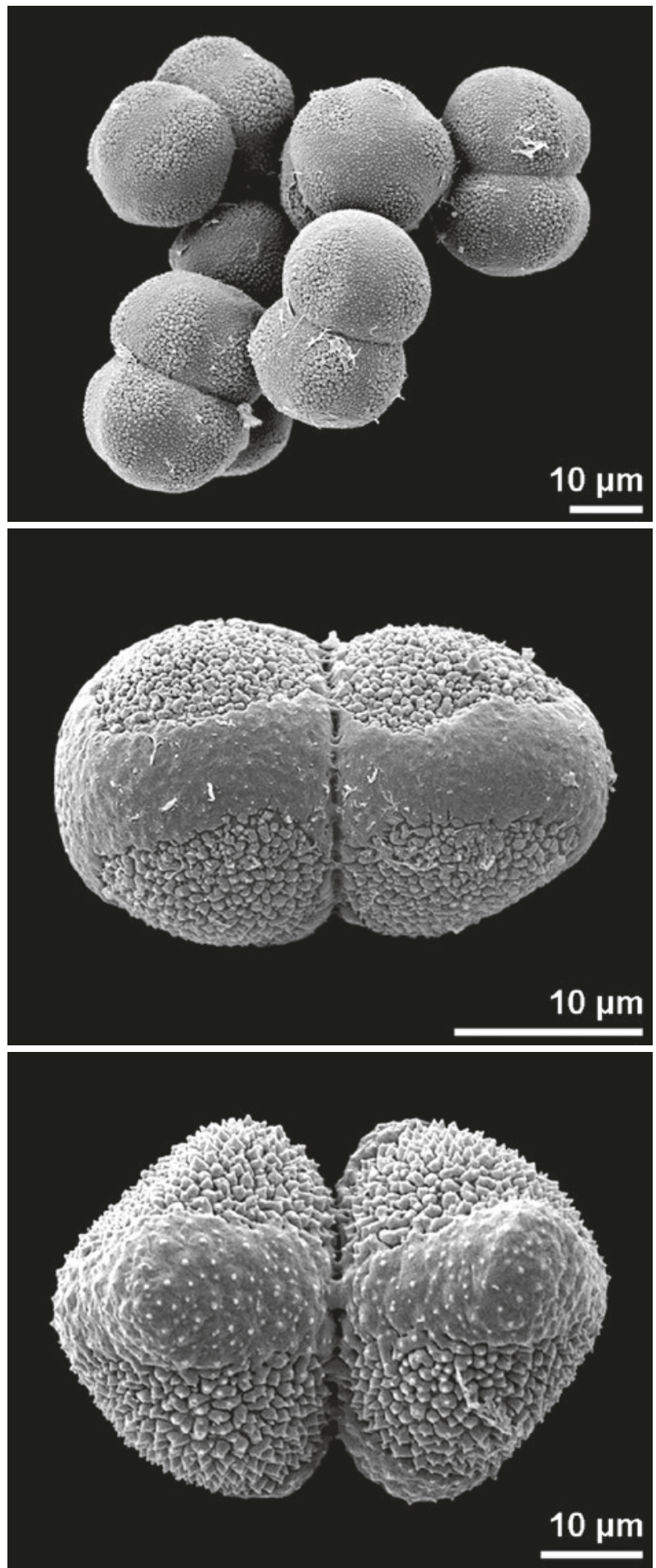

- Polypleurum stylosum, Podostemaceae

Zeylanidium olivaceum, Podostemaceae equatorial view

Thelethylax minutiflora, Podostemaceae

- equatorial view
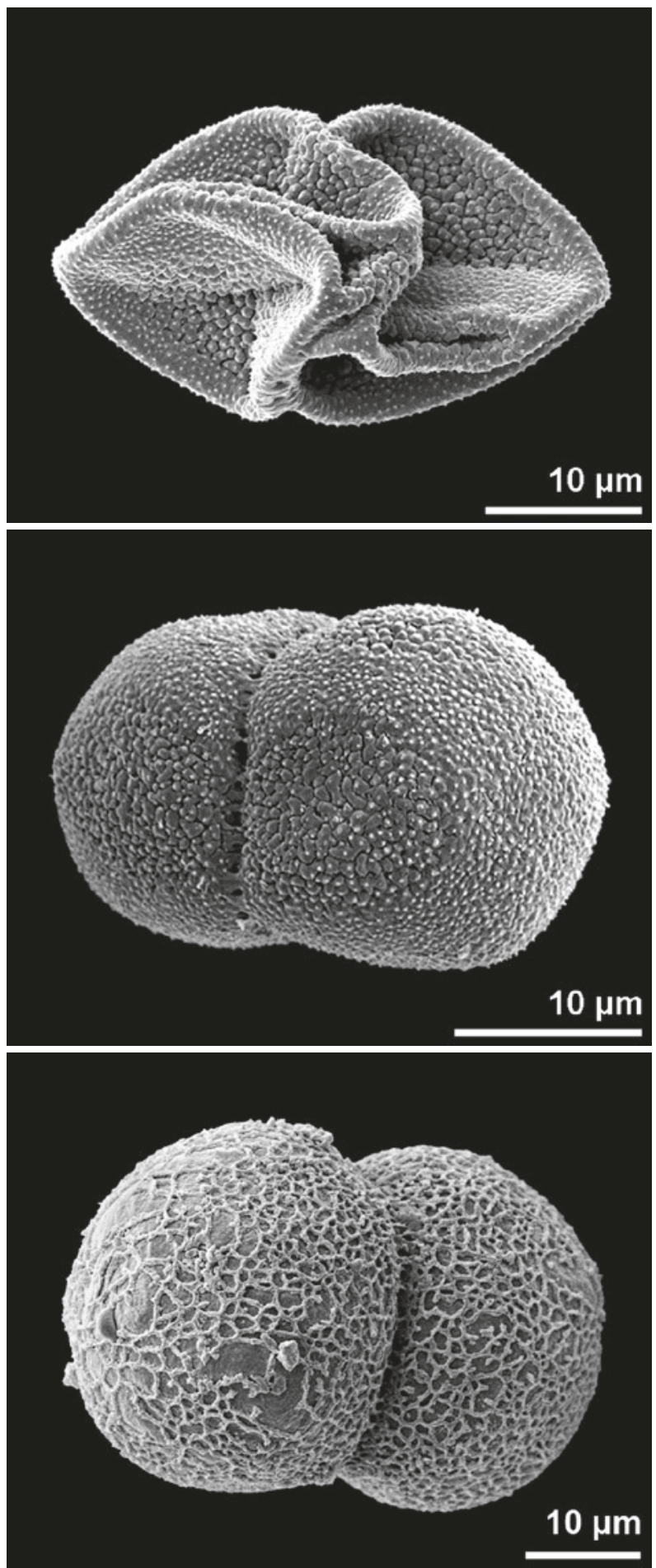

Polypleurum stylosum, Podostemaceae pollen collapsed

Zeylanidium subulatum, Podostemaceae

Scheuchzeria palustris, Scheuchzeriaceae 


\section{pseudomonad}

unit of a permanent tetrad with three rudimentary pollen grains
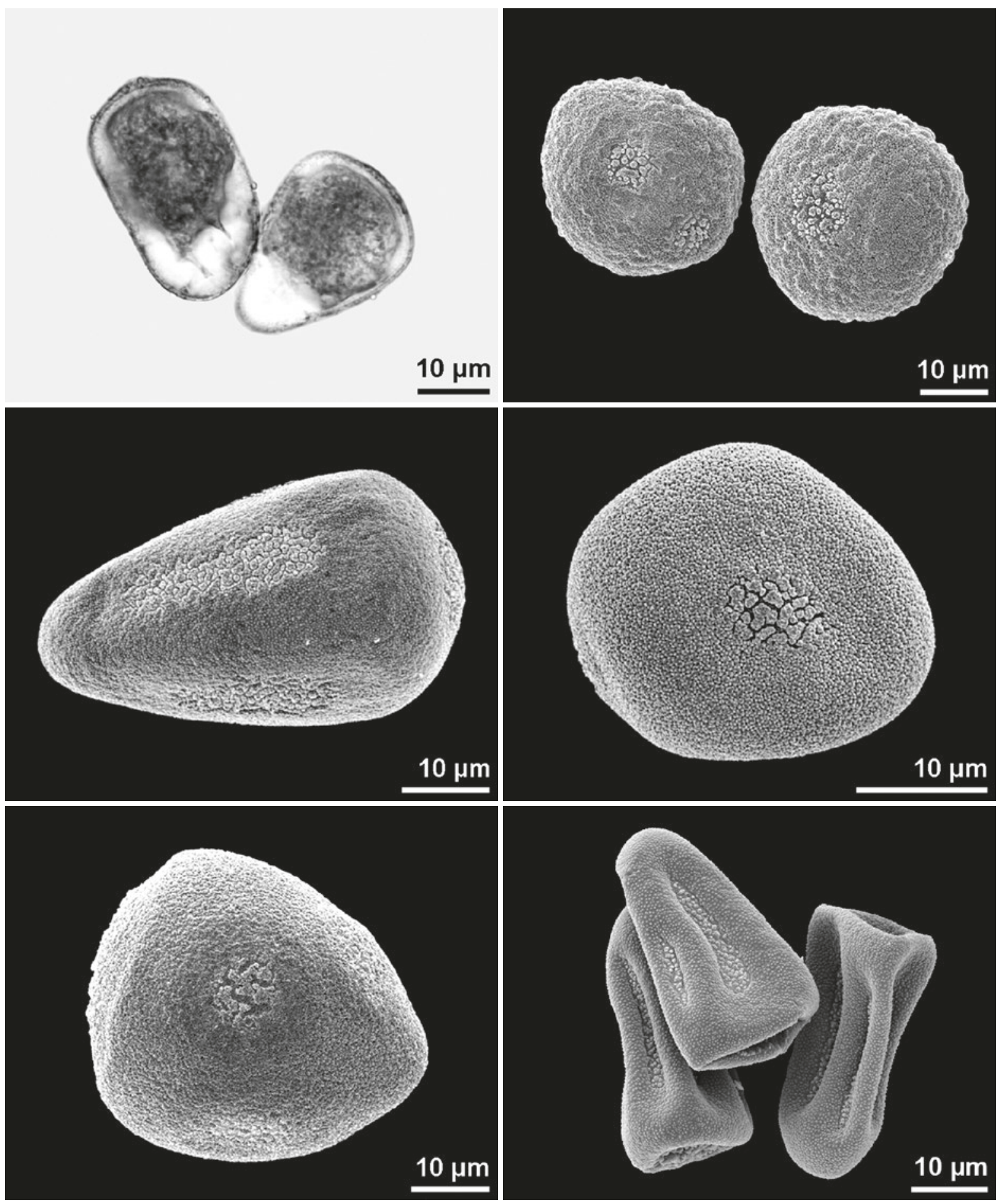
- Carex sp., Cyperaceae
hydrated pseudomonads, note remnants of aborted
pollen at proximal pole (white zone)

- Schoenoplectus lacustris, Cyperaceae equatorial view

- Carex atrata, Cyperaceae Scirpus sylvaticus, Cyperaceae
equatorial view

Carex distans, Cyperaceae

- equatorial view 

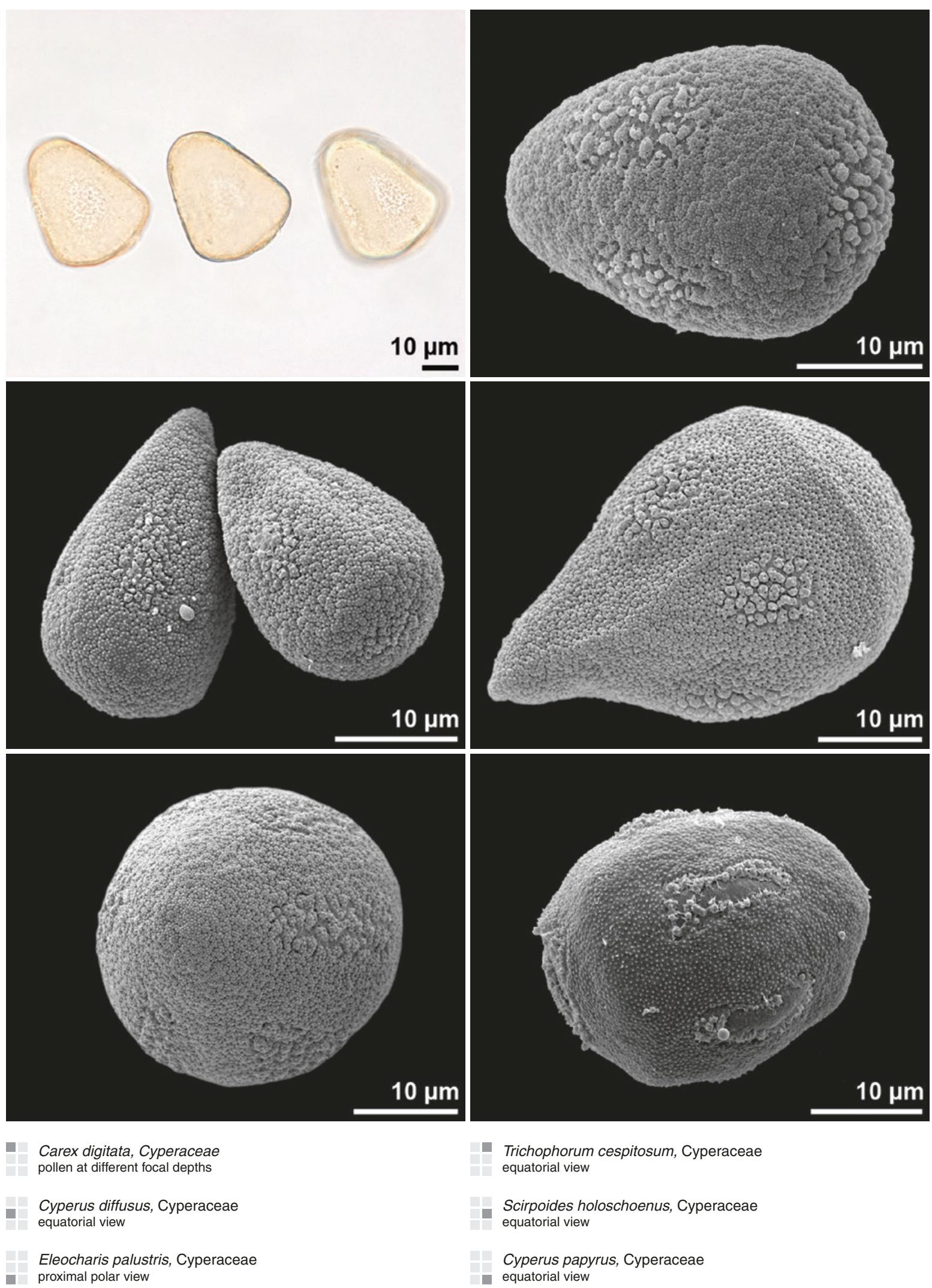

- Trichophorum cespitosum, Cyperaceae equatorial view Scirpoides holoschoenus, Cyperaceae
equatorial view

Cyperus papyrus, Cyperaceae

- equatorial view 
tetrad

unit of four pollen grains
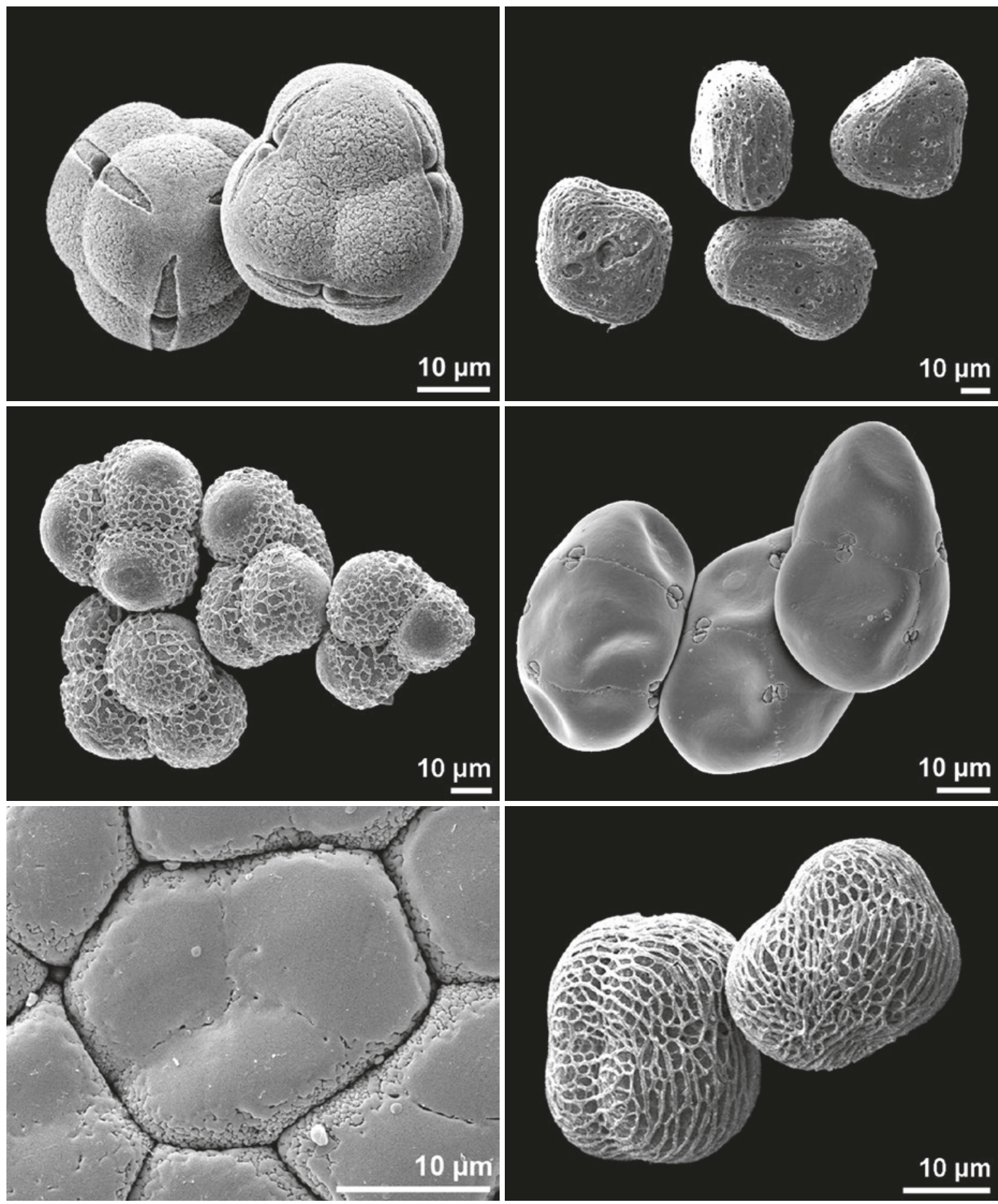

- Erica herbacea, Ericaceae
- Chlorospatha kolbii, Araceae
differnt planar tetrads
- Cyprinia gracilis, Apocynaceae
planar tetrads, dry pollen
Xanthosoma ceronii, Araceae
- tetrad planar (left) and decussate (right)

Epidendrum centropetalum, Orchidaceae

- tetrad, part of pollinium 


\section{tetrad tetrahedral}

unit of four pollen grains in which the centers of the grains define a tetrahedron
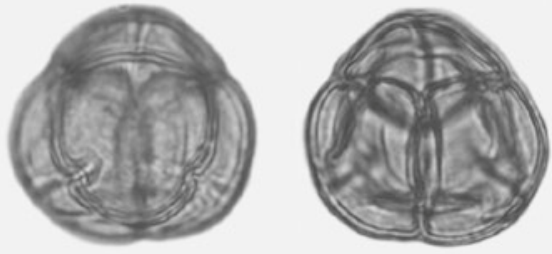

$10 \mu \mathrm{m}$
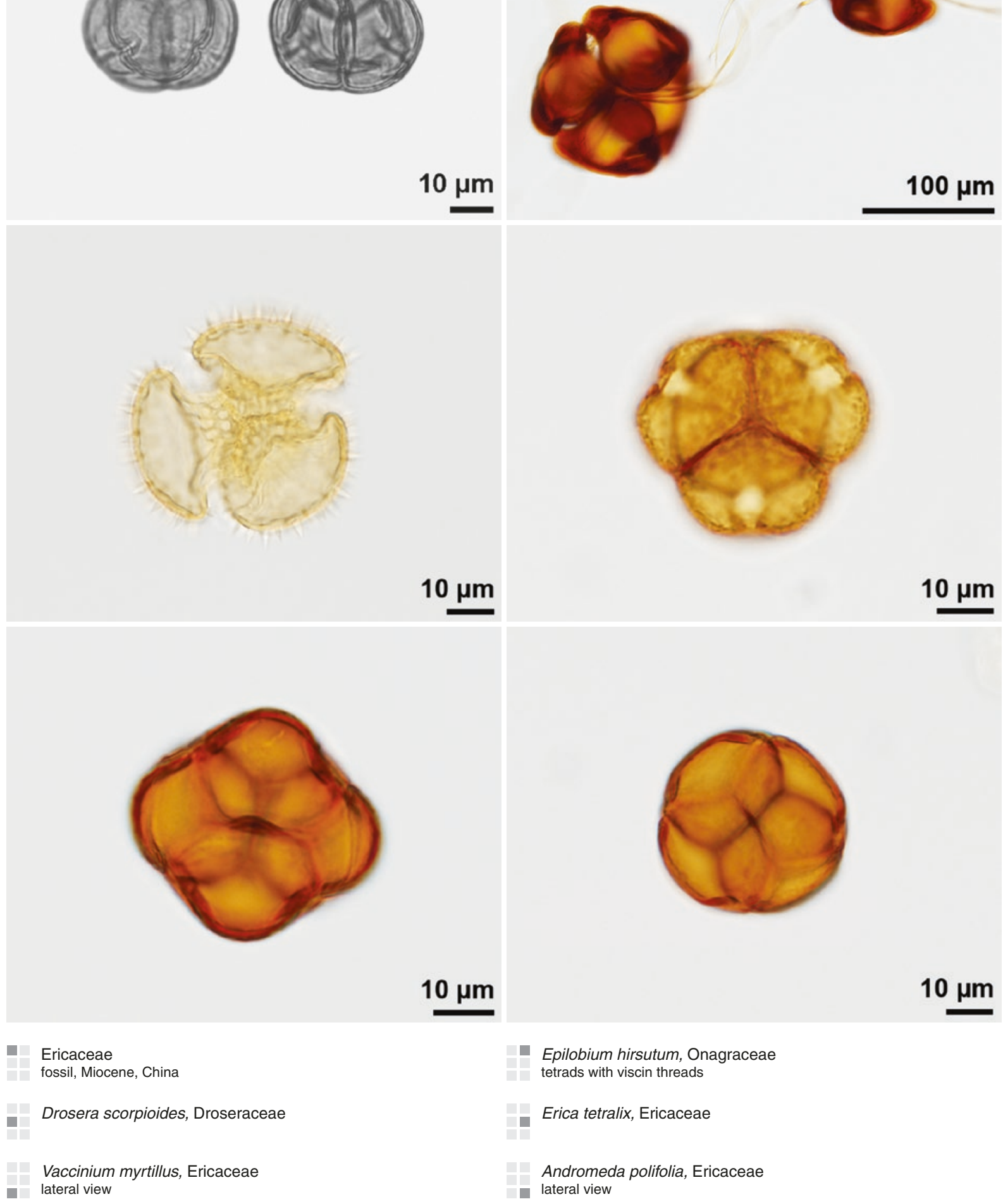

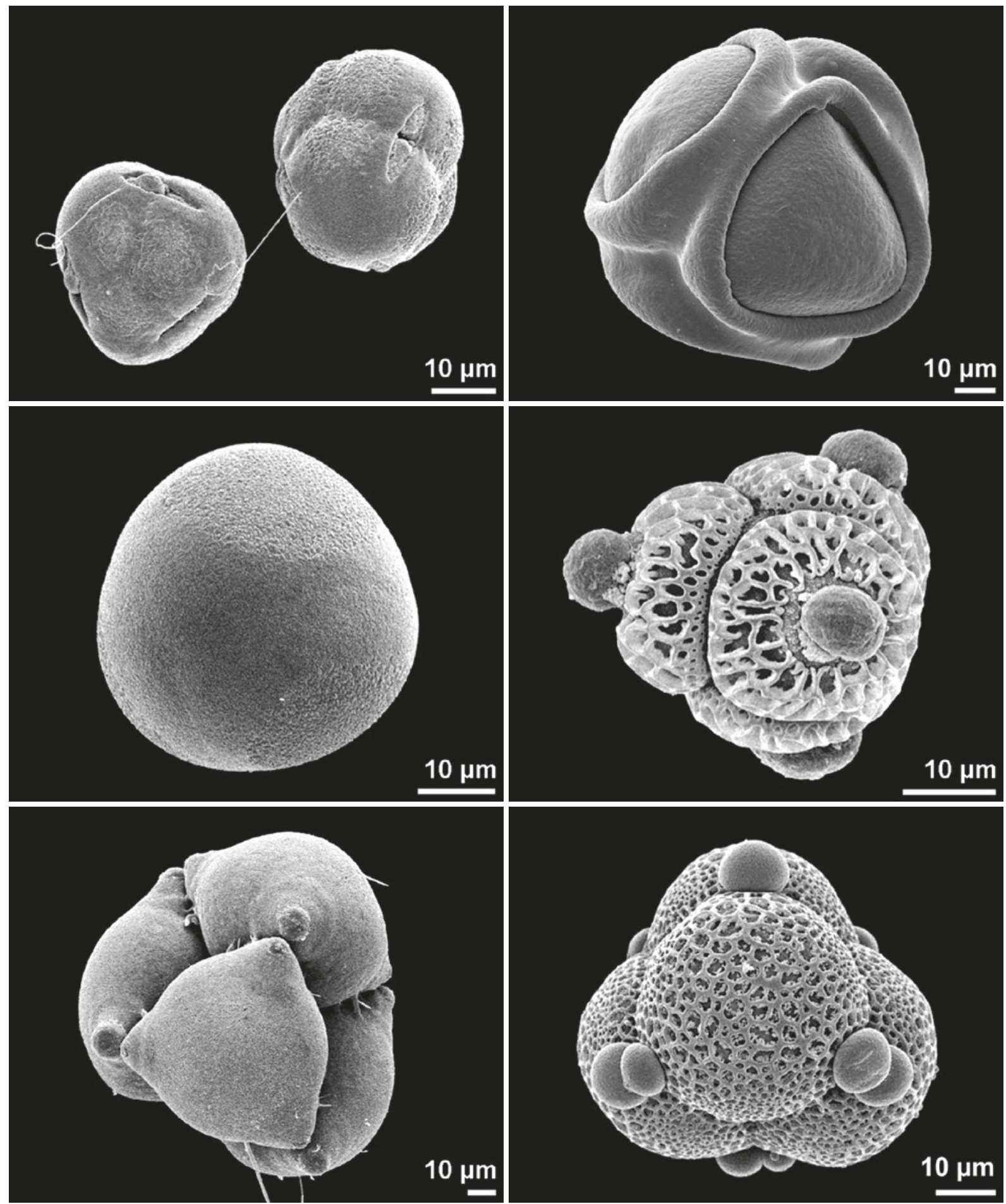

- Rhododendron hirsutum, Ericaceae tetrads with viscin threads

$10 \mu \mathrm{m}$

Victoria regia, Nymphaeaceae dry pollen

Drimys granatensis, Winteraceae

Luzula campestris, Juncaceae ulcerate pollen ulcerate pollen 

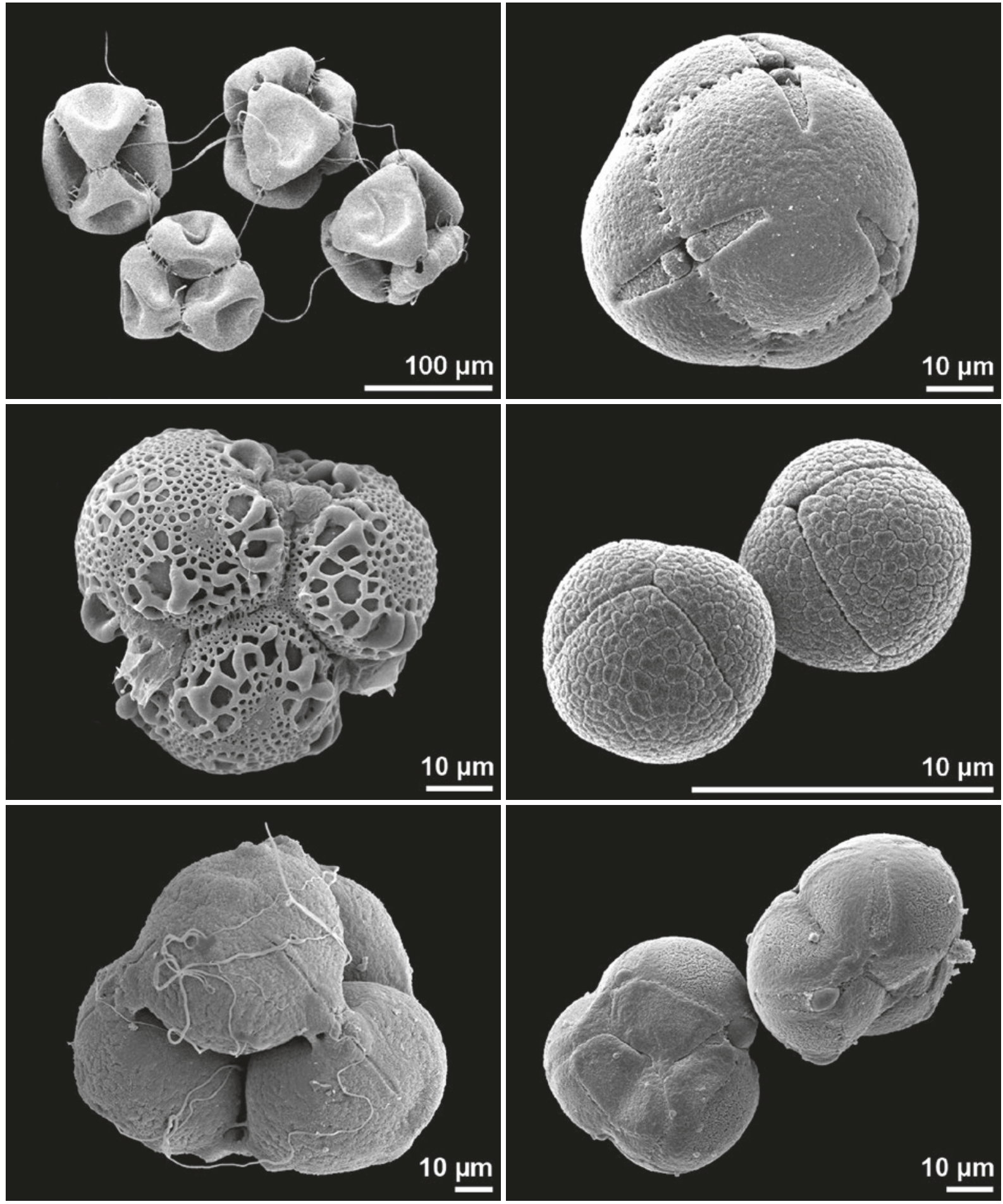

- Epilobium parviflorum, Onagraceae

- Arbutus unedo, Ericaceae tetrads with viscin threads, dry pollen

Mimosa pudica, Mimosaceae

- Chelonanthus alatus, Gentianaceae basal view 

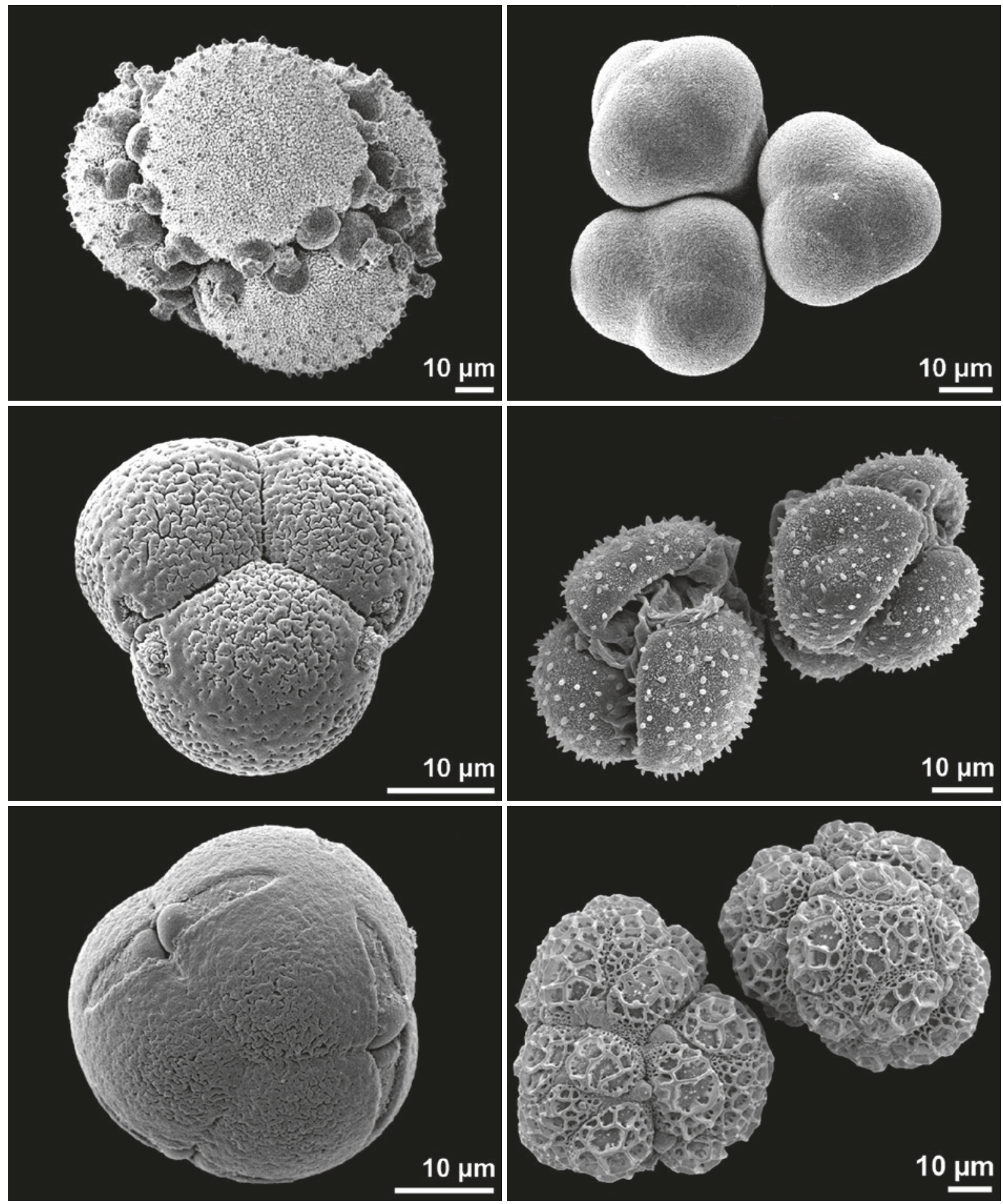

- Dionaea muscipula, Droseraceae

- Juncus effusus, Juncaceae ulcerate pollen

Moneses uniflora, Ericaceae

Drosera binata, Droseraceae basal view dry pollen 


\section{tetrad decussate}

unit of four pollen grains arranged in two pairs in two different plains

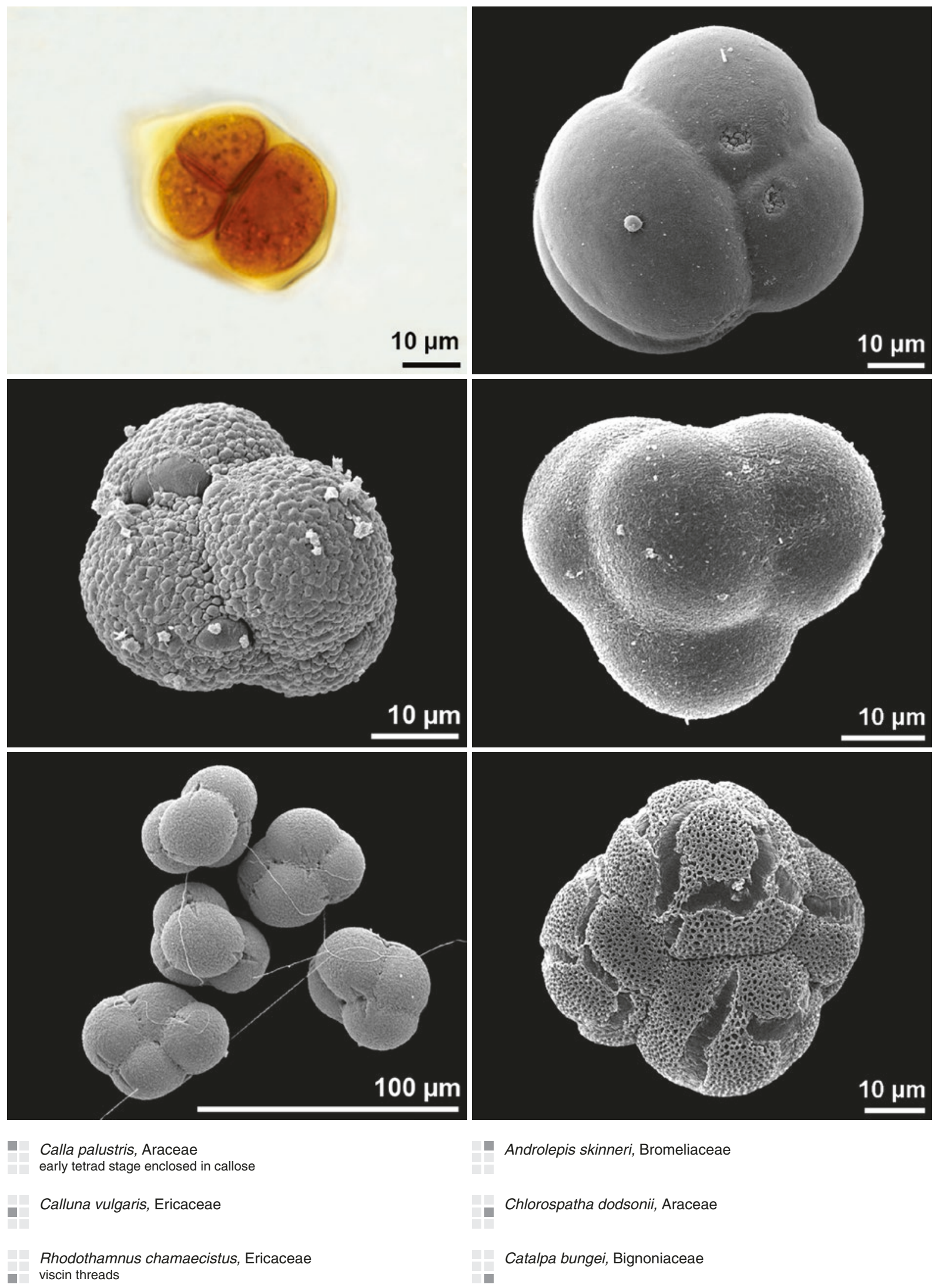


tetrad planar

unit of four pollen grains arranged in one plane: tetragonal, T-shaped, linear
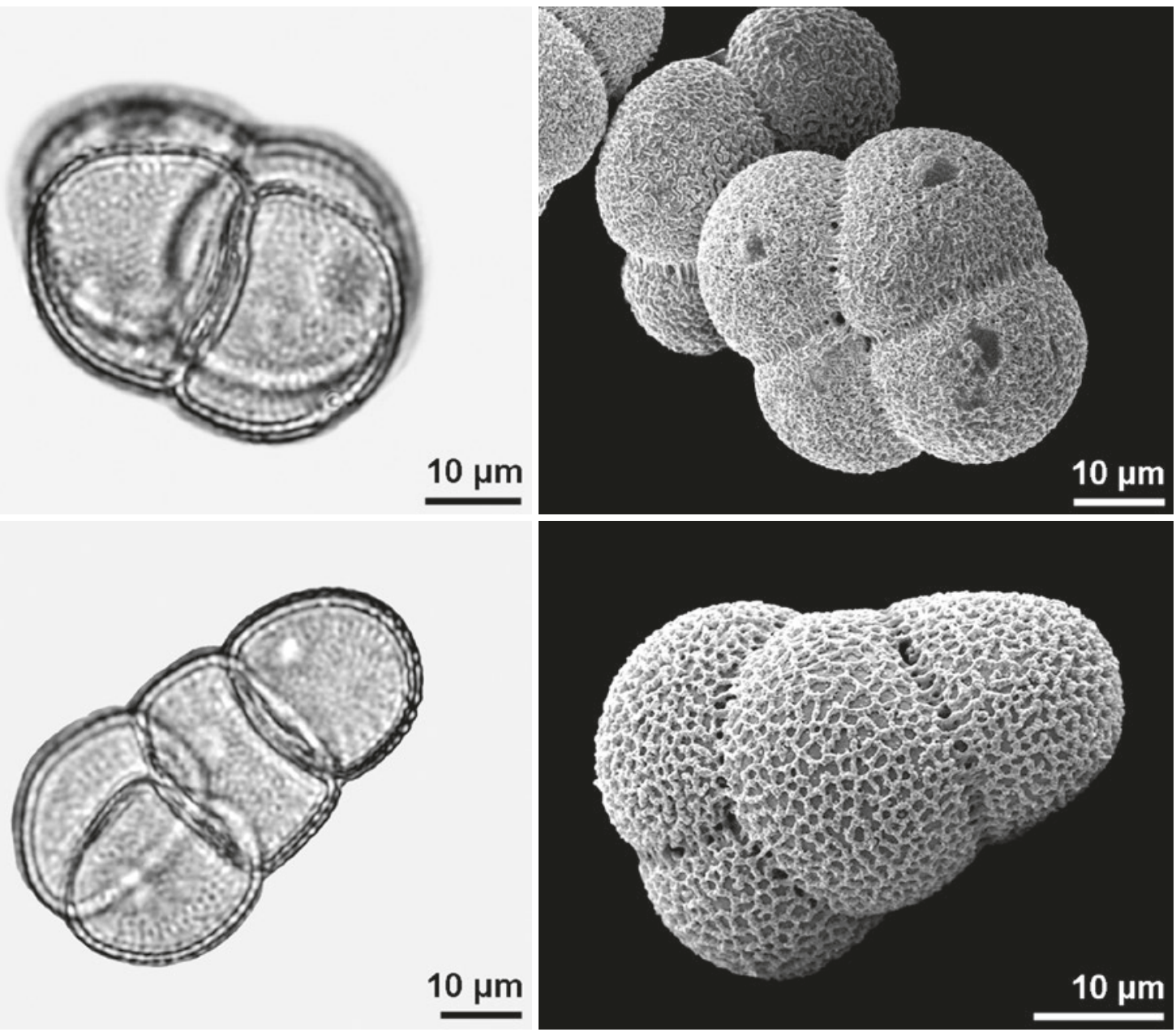

$10 \mu \mathrm{m}$
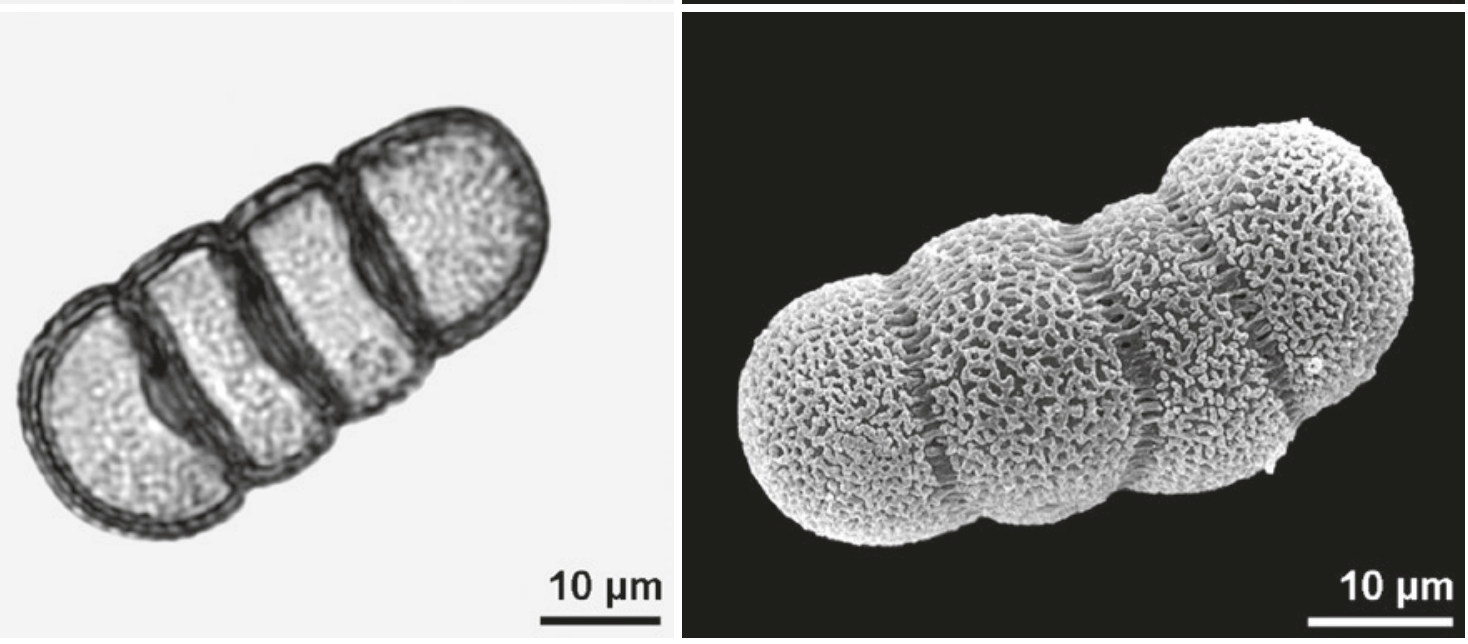

$10 \mu \mathrm{m}$

- Typha latifolia, Typhaceae

- Typha latifolia, Typhaceae tetrad tetragonal

- Typha latifolia, Typhaceae tetrad T-shaped

Typha latifolia, Typhaceae tetrad linear 

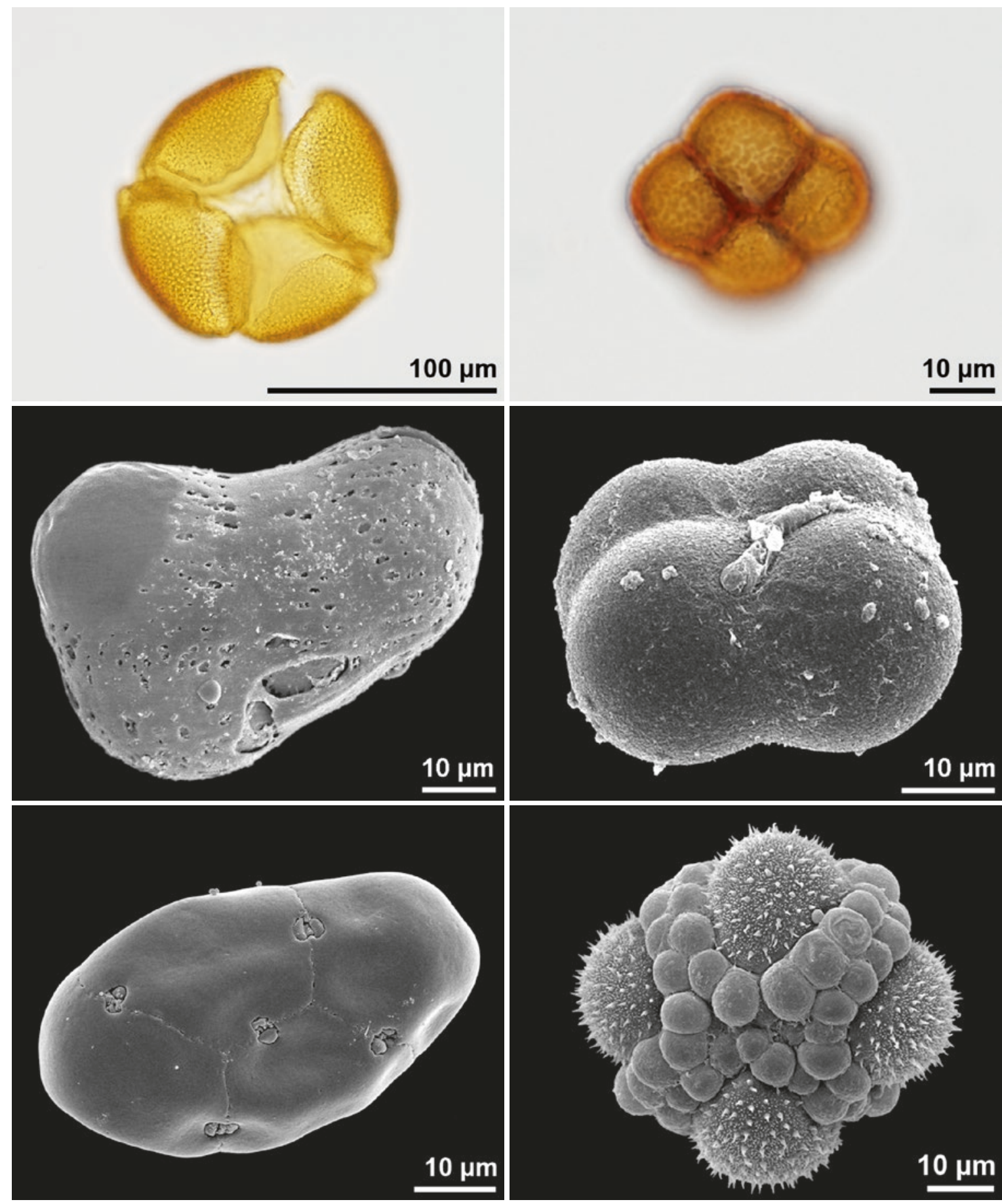

- Asimina triloba, Annonaceae

Calluna vulgaris, Ericaceae tetrad tetragonal tetrad tetragonal

Chlorospatha kolbii, Araceae tetrad T-shaped

- Chlorospatha dodsonii, Araceae tetrad tetragonal

Cyprinia gracilis, Apocynaceae

- tetrad planar, dry pollen

Drosera peltata, Droseraceae tetrad tetragonal 


\section{polyad}

unit of more than four pollen grains (multiple of 4)
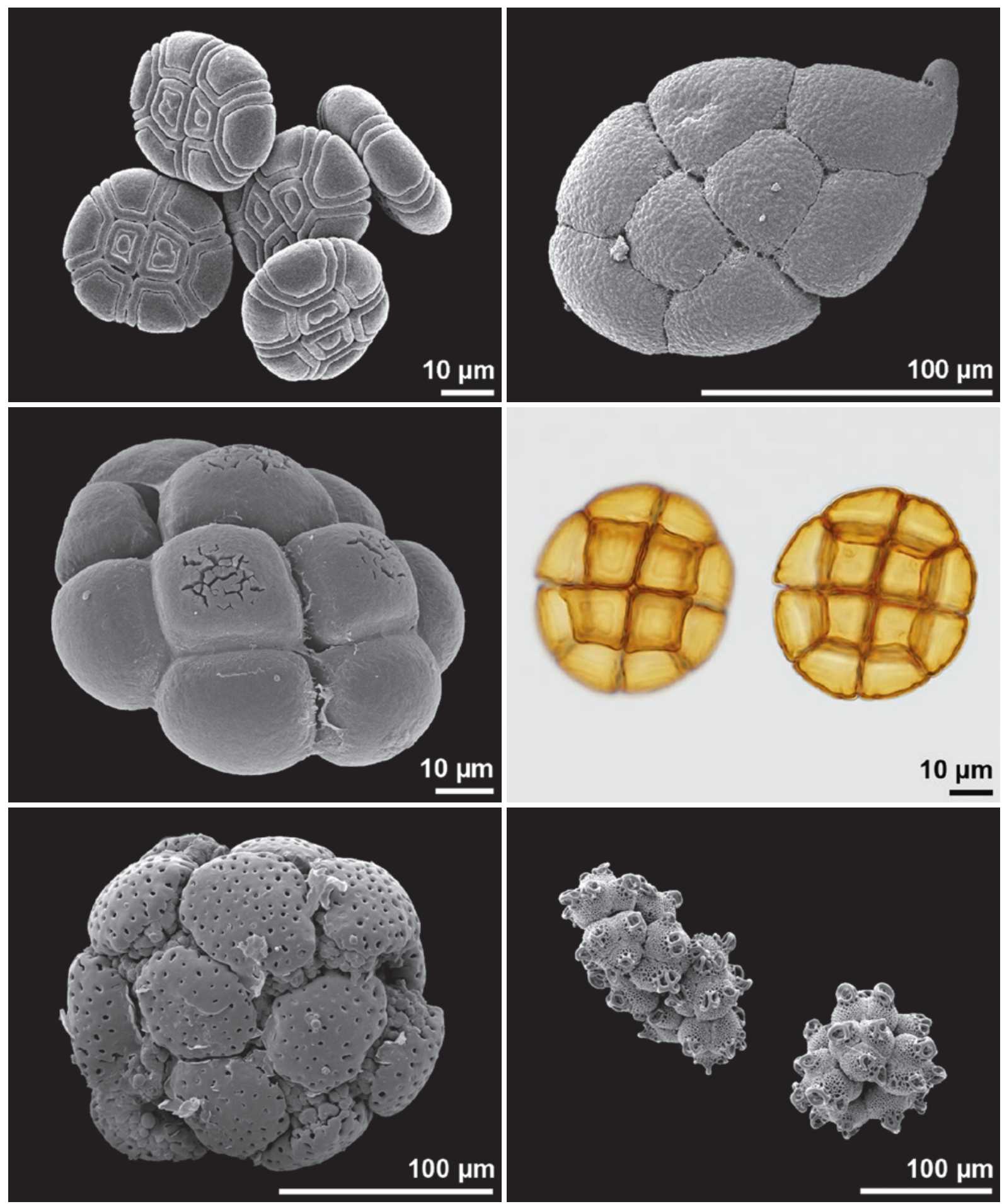

- Acacia myrtifolia, Fabaceae

- Calliandra tergemina, Fabaceae polyad with 8 monads, dry pollen polyad with 8 monads

Acacia sp., Fabaceae
polyad with 16 monads

Pithecellobium dulce, Fabaceae polyad with 16 monads

Chelonanthus purpurascens, Gentianaceae

Cymbopetalum aequale, Annonaceae

polyad with 16 monads polyad with 32 monads (8 united tetrads) 

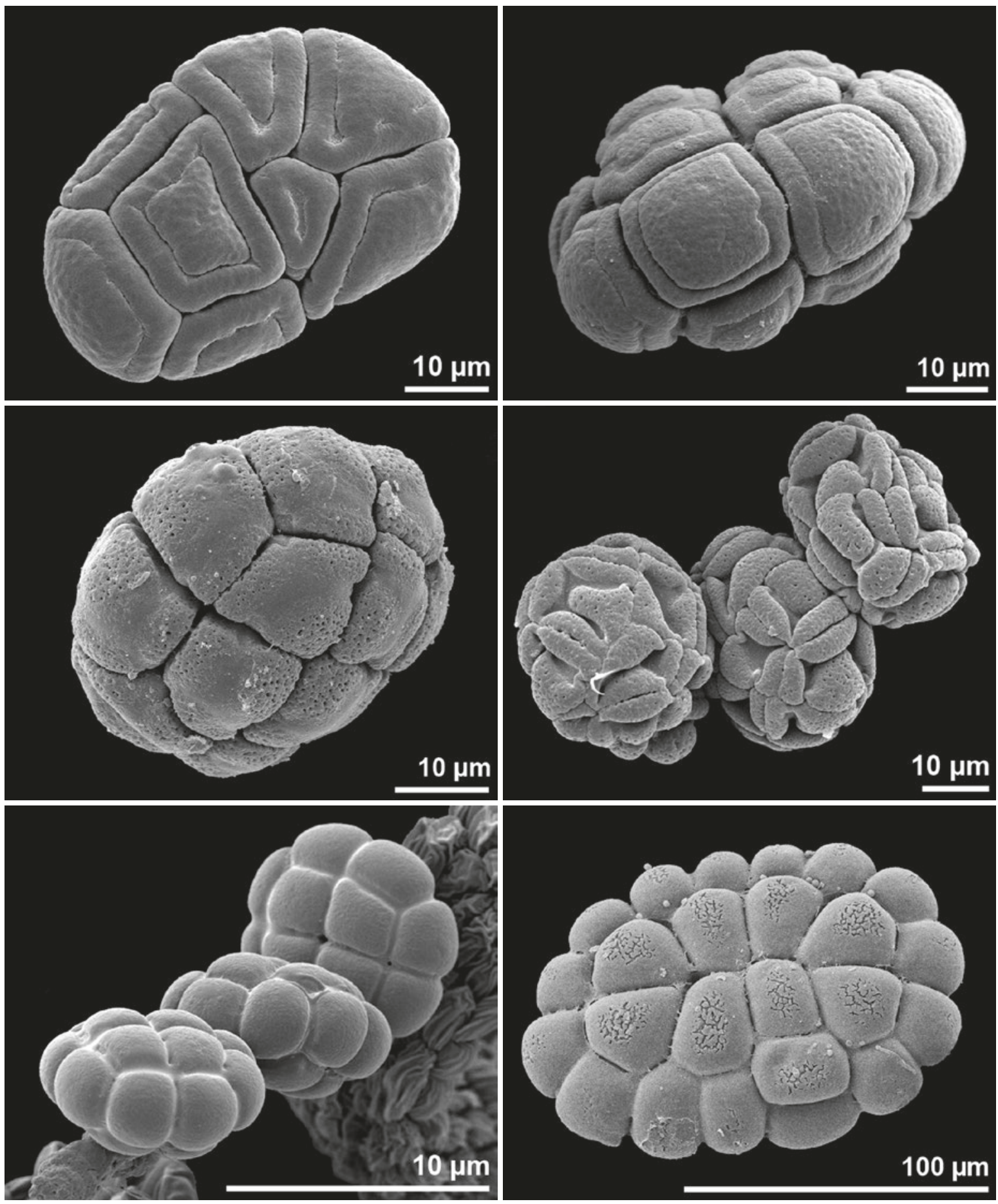

\footnotetext{
- Acacia sp., Fabaceae

- Acacia karroo, Fabaceae

polyad with 16 monads

Albizia julibrissin, Fabaceae

- polyad with 16 monads
}

polyad of 8 monads, irregularly arranged, dry pollen

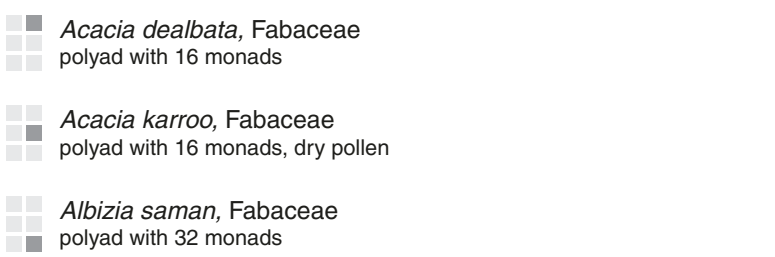




\section{massula}

unit of more than four pollen grains but less than the locular content of a theca

Comment: In angiosperms only used for Orchidaceae with sectile pollinia
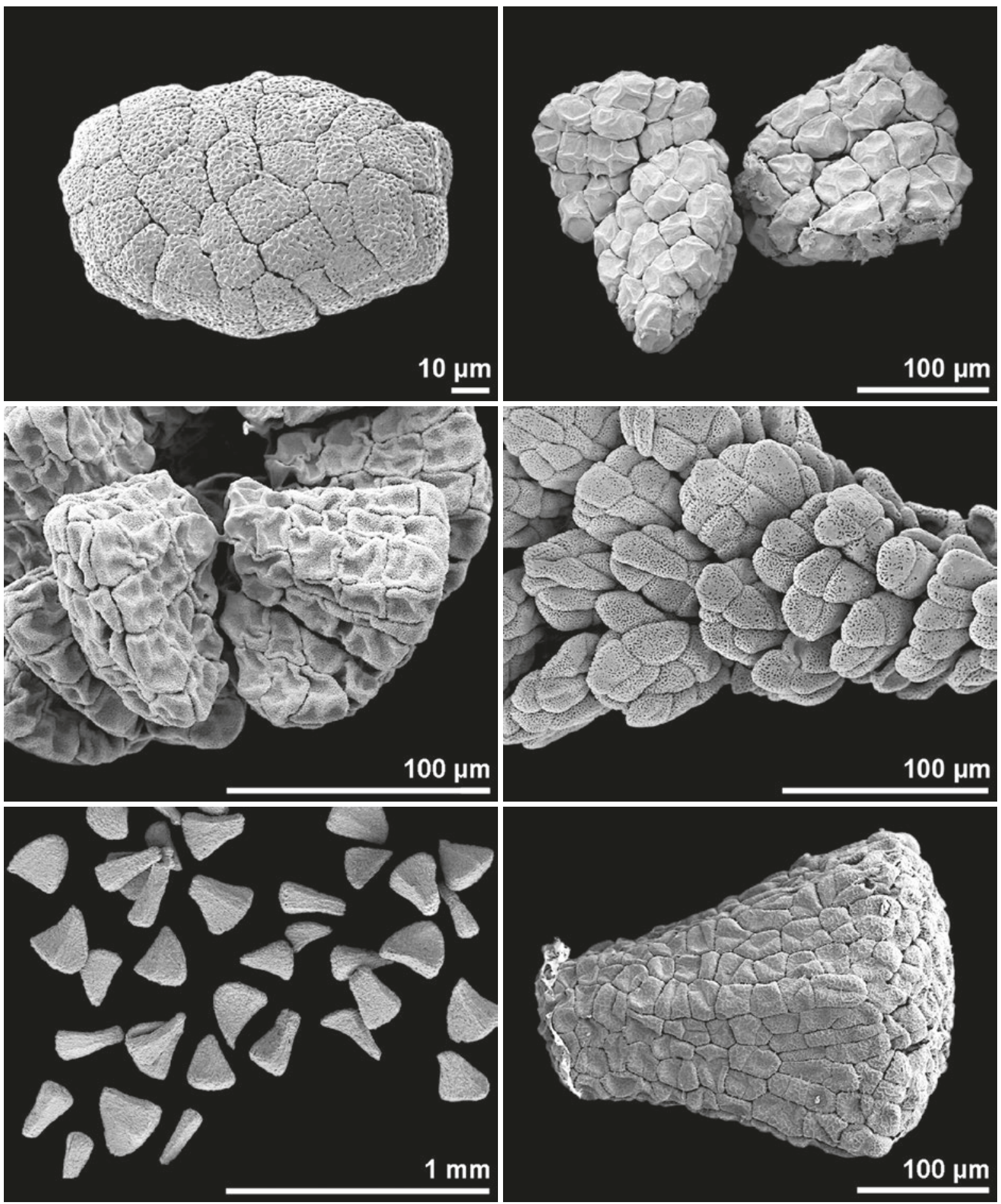

- Traunsteinera globosa, Orchidaceae

- Epipogium aphyllum, Orchidaceae

- Herminium monorchis, Orchidaceae

- Gennaria diphylla, Orchidaceae massulae forming pollinium

massulae forming pollinium

Orchis italica, Orchidaceae

Orchis purpurea, Orchidaceae 
pollinium

unit of a more or less interconnected loculiform pollen mass

Comment: loculi may be subdivided by septae, thus resulting in more than two pollinia
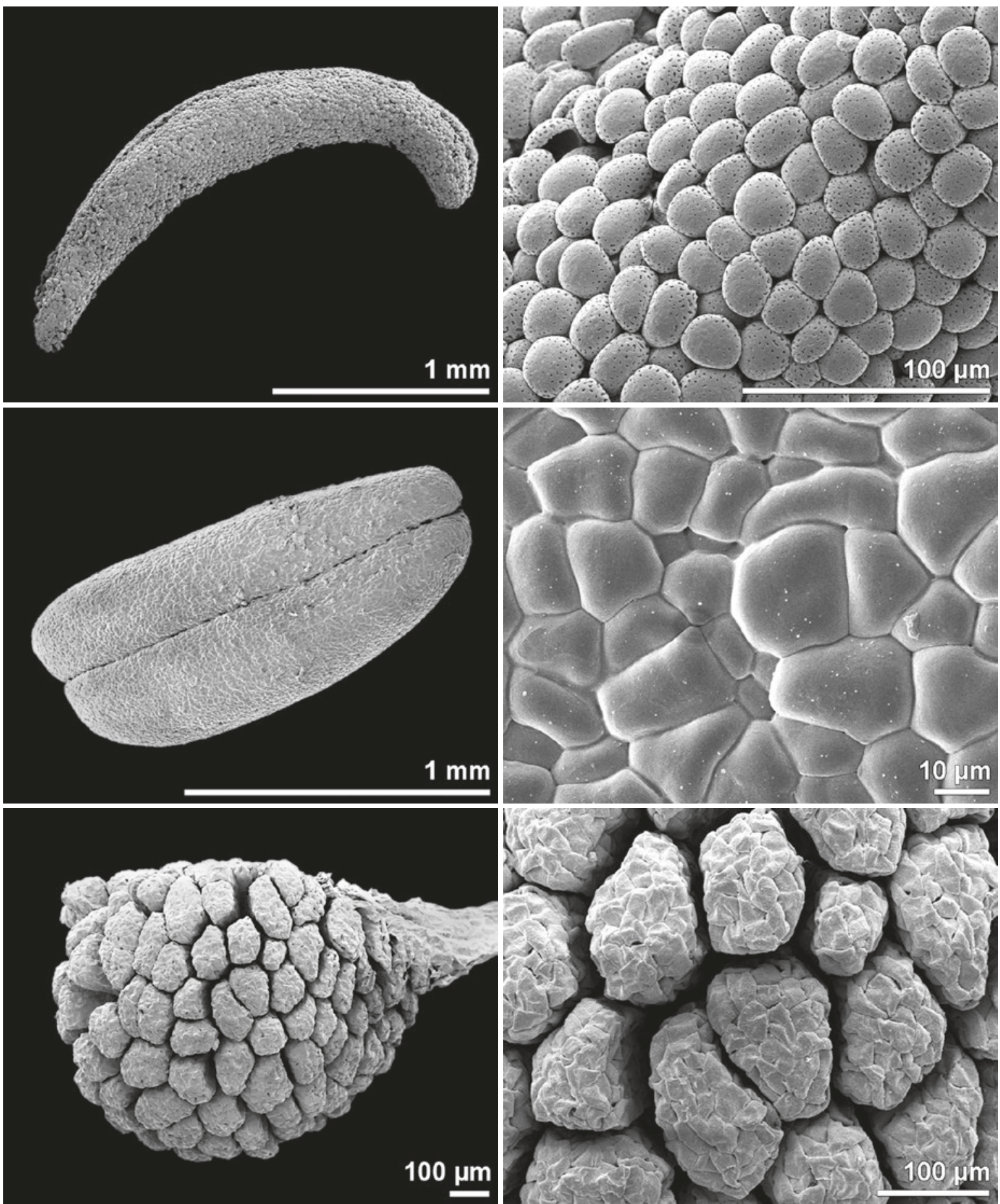

- Cephalanthera Iongifolia, Orchidaceae

- Cephalanthera longifolia, Orchidaceae detail (monads)

Dendrobium farmeri, Orchidaceae

Dendrobium farmeri, Orchidaceae
detail (tetrads)

Steveniella satyrioides, Orchidaceae - sectile pollinium

Steveniella satyrioides, Orchidaceae

- sectile pollinium, detail (massulae) 

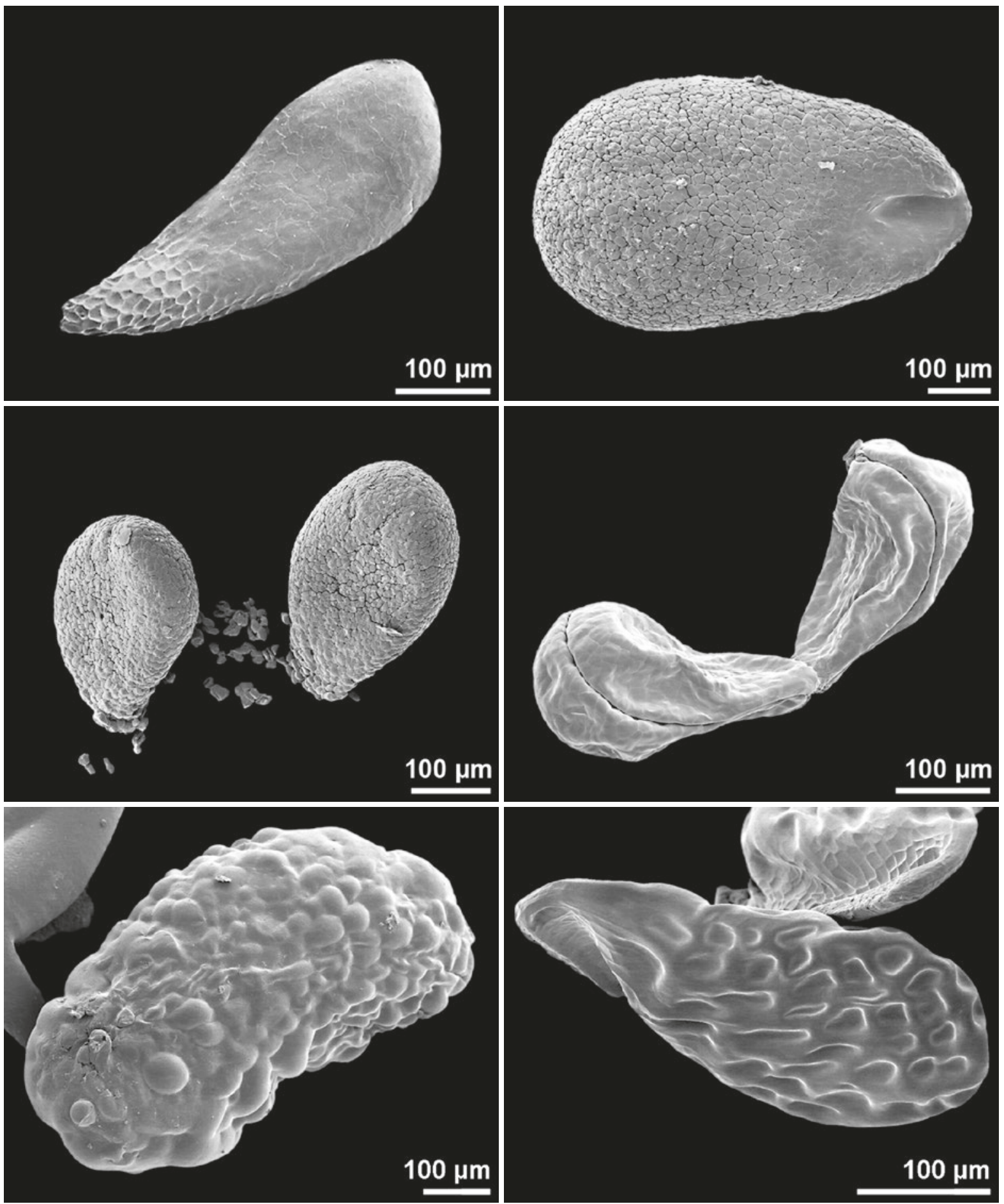

- Hammarbya paludosa, Orchidaceae

- Plectrophora cultrifolia, Orchidaceae

Restrepia muscifera, Orchidacea 2 pollinia

- Malaxis monophyllos, Orchidaceae 4 pollinia

Stephanotis floribunda, Asclepiadaceae

口

Hoodia flava, Asclepiadaceae 


\section{pollinarium}

dispersal unit of pollinium (or pollinia) plus secretions and/or tissues that aid in the removal of the structure from the flower
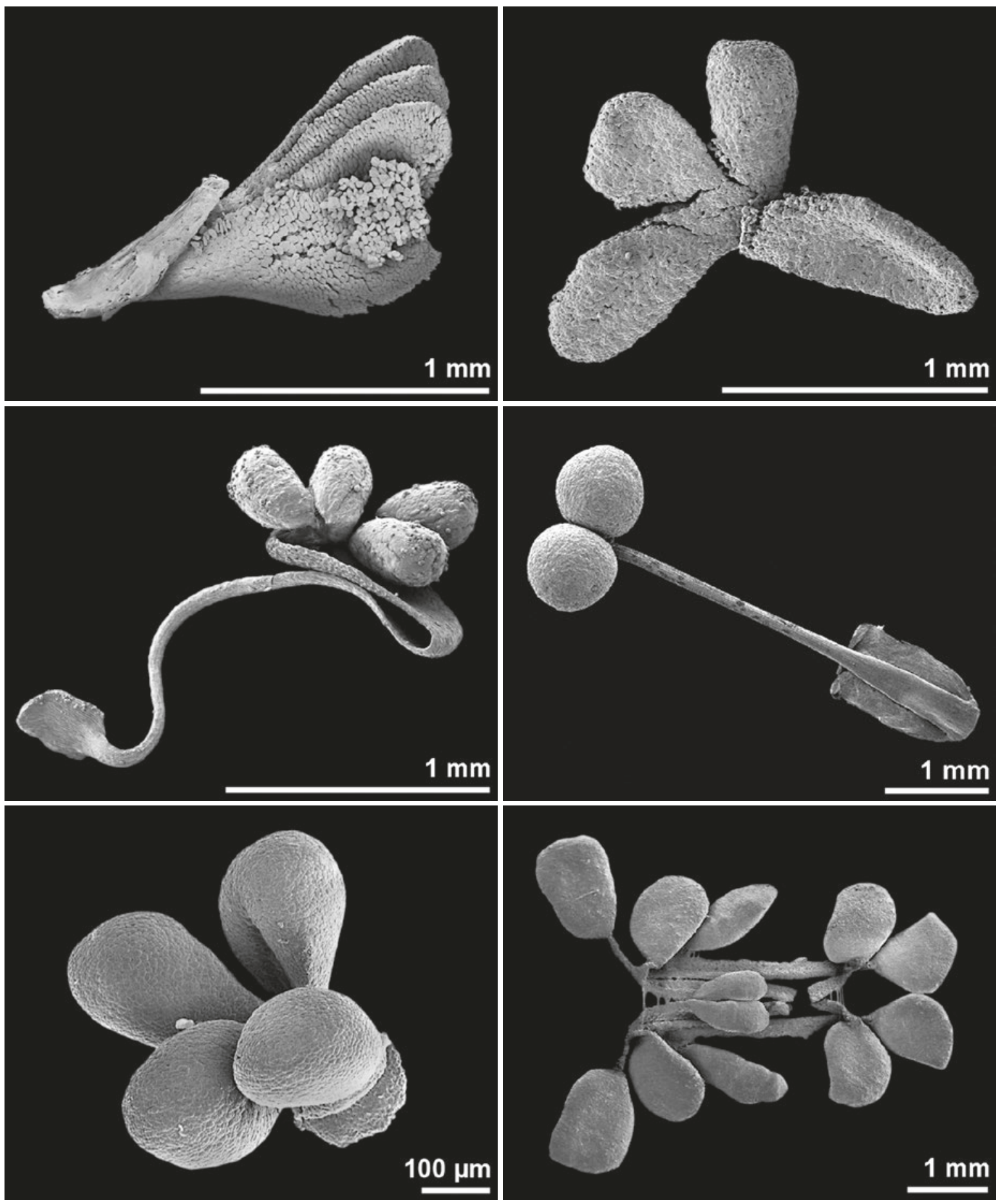

- Spiranthes spiralis, Orchidaceae

- Caladenia latifolia, Orchidaceae

Ornithocephalus myrticola, Orchidaceae

n Aerides multiflora, Orchidaceae

Maxillaria densa, Orchidaceae

Brassavola cucullata, Orchidaceae

12 pollinia 

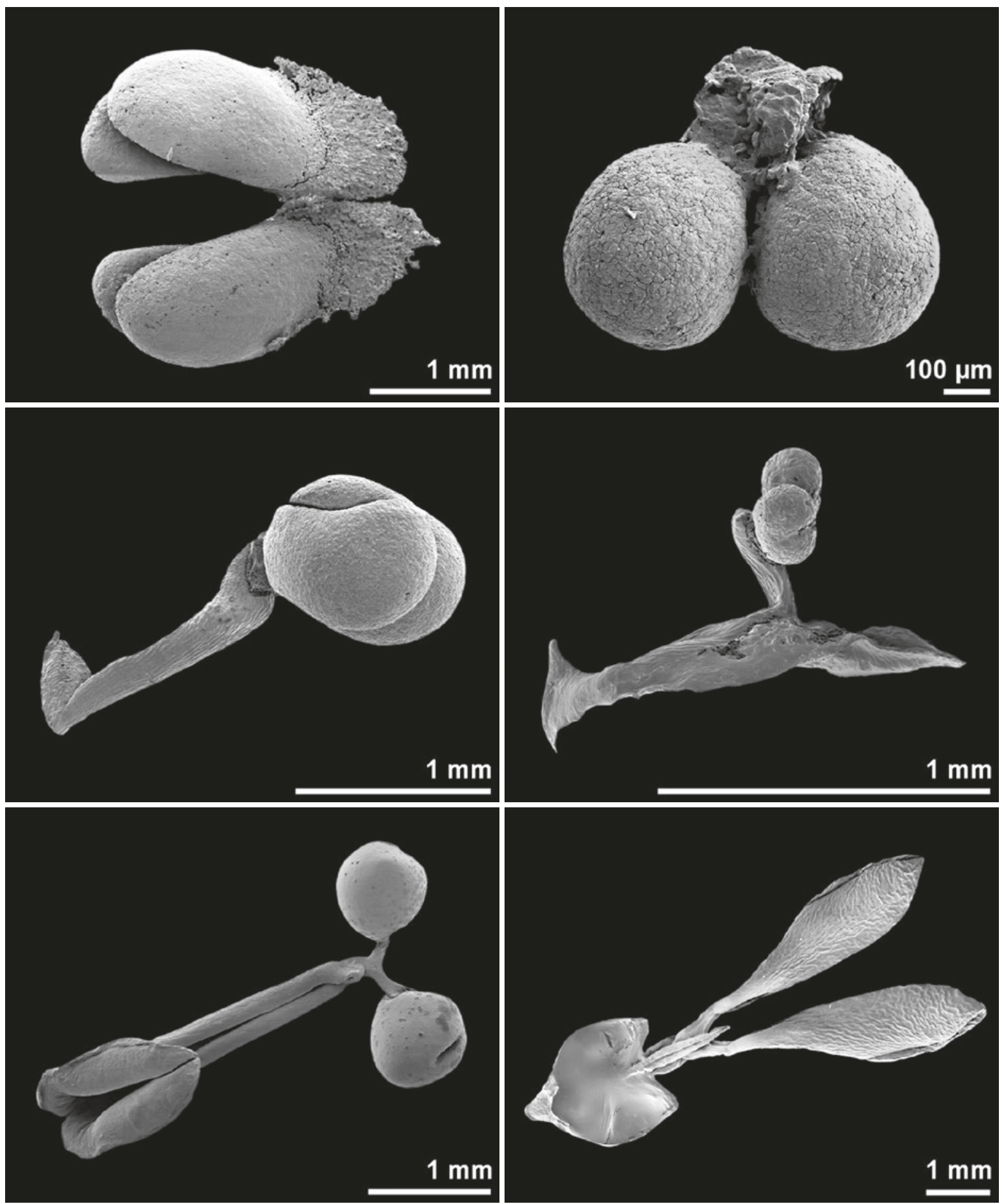

- Coelogyne fimbriata, Orchidaceae

- Pleurothallis loranthophylla, Orchidaceae

- Oncidium maizaefolium, Orchidaceae

- Schoenorchis fragrans, Orchidaceae

Haraella odorata, Orchidaceae

Stanhopea oculata, Orchidaceae 

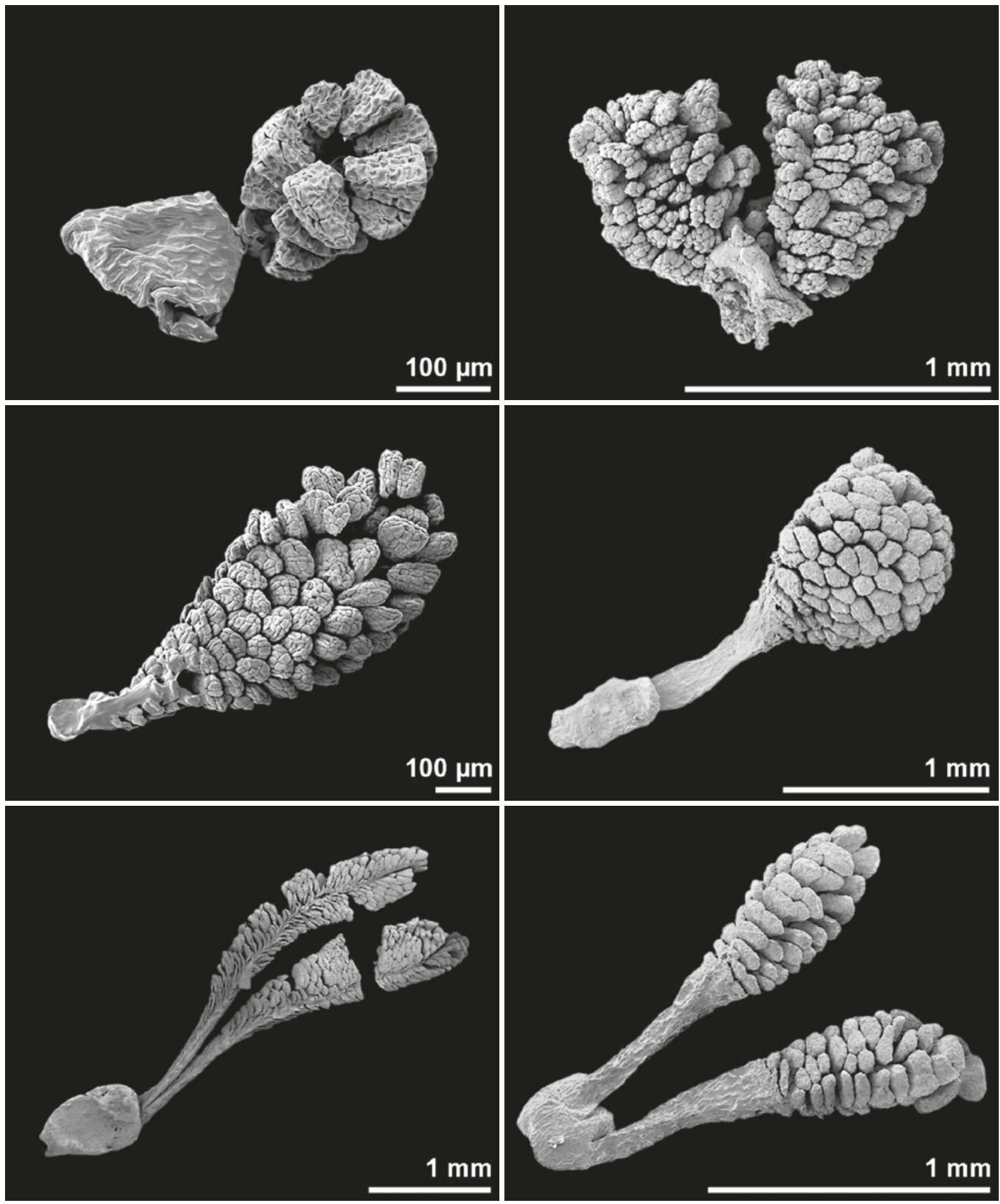

- Herminium monorchis, Orchidaceae

- Goodyera repens, Orchidaceae

- Gennaria diphylla, Orchidaceae

Steveniella satyrioides, Orchidaceae

Ludisia discolor, Orchidaceae

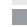

Anacamptis pyramidalis, Orchidaceae

- 

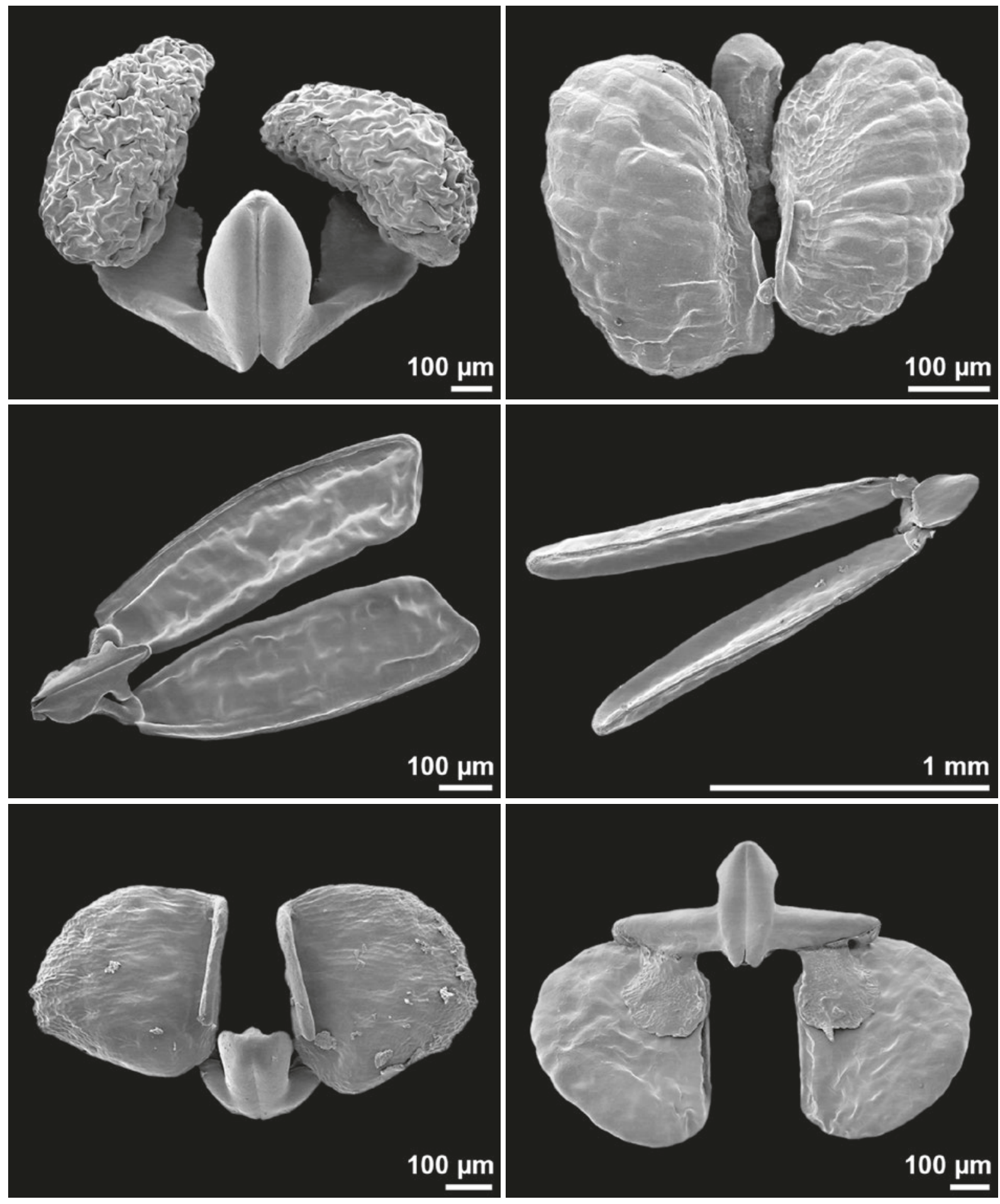

- Stephanotis floribunda, Asclepiadaceae

- Ceropegia sandersonii, Asclepiadaceae

Hoya carnosa, Asclepiadaceae

- Hoya multiflora, Asclepiadaceae

Frerea indica, Asclepiadaceae

Orbeanthus hardyi, Asclepiadaceae 
Open Access This chapter is licensed under the terms of the Creative Commons Attribution 4.0 International License (http://creativecommons.org/licenses/by/4.0/), which permits use, sharing, adaptation, distribution and reproduction in any medium or format, as long as you give appropriate credit to the original author(s) and the source, provide a link to the Creative Commons license and indicate if changes were made.

The images or other third party material in this chapter are included in the chapter's Creative Commons license, unless indicated otherwise in a credit line to the material. If material is not included in the chapter's Creative Commons license and your intended use is not permitted by statutory regulation or exceeds the permitted use, you will need to obtain permission directly from the copyright holder.

(c) (i) 